(RESEARCH ARTICLE)

\title{
Construction of local volume table for natural mangroves in Peninsular Malaysia: case study of Sungai Merbok Forest Reserve, Kedah
}

\author{
Salim Aman ${ }^{1}$ and Ismail P 2,* \\ ${ }^{1}$ Forestry Department Peninsular Malaysia (FDPM), Jalan Sultan Salahuddin 50660 Kuala Lumpur, Malaysia. \\ 2 Forest Research Institute Malaysia (FRIM), Kepong 52109 Selangor, Malaysia.
}

Publication history: Received on 13 August 2020; revised on 26 August 2020; accepted on 29 August 2020

Article DOI: https://doi.org/10.30574/wjarr.2020.7.2.0305

\begin{abstract}
Tree volume tables have been recognized as one of the fundamental requirements in forest mensuration and management for providing estimates of timber volume to determine sustained yield and periodic increment. Mangroves one on important forests available in this country which also produced timber particularly for charcoal production. Thus, this study aimed at developing local volume tables for natural mangroves of Sungai Merbok Forest Reserve in Kedah. Two volume tables were developed for Bakau species (Rhizophora apiculata \& R. mucronata) and Non-Bakau species (other species) based on relation between diameter at breast height (dbh) and gross stem volume (under bark and over bark). Test of accuracy by means of standard statistical measures and relative measures, were made on all equations, where the smallest value of mean square error (MSE) and mean absolute percentage error (MAPE) as the criteria for the best fitted equation to develop the local volume table. The local volume tables for Sungai Merbok Forest R e s e rve were constructed based on "allometric model" which were solved by mean of weighted least square (WLS). Practically, these volume table can be applied within the area, and not applicable to estimate timber volume in other mangroves areas. Nonetheless, other mangroves areas that having similar condition with Sungai Merbok Forest Reserve as natural mangroves may use the volume table until they construct for their own. Based on this study, the best fitted equations to construct local volume table for Sungai Merbok Forest Reserve are as follows:
\end{abstract}

Bakau species: $\mathrm{V}_{\mathrm{ob}}=0.00045 \mathrm{D}^{2.02248} \mathrm{~V}_{\mathrm{ub}}=0.00040 \mathrm{D}^{2.04390}$

Non-Bakau species: $\mathrm{V}_{\mathrm{ob}}=0.00088 \mathrm{D}^{1.69929} \mathrm{~V}_{\mathrm{ub}}=0.00084 \mathrm{D}^{1.70310}$

Note: $V_{o b}=$ Over bark, $V_{u b}=$ Under bark and $\mathrm{D}=\mathrm{dbh}$ in $\mathrm{cm}$

Keywords: Tree volume; Allometric model; Natural mangroves; Bakau species; Non-Bakau species; Malaysia

\section{Introduction}

This study was conducted to derive volume equations and to construct a local volume table for Sungai Merbok Forest Reserve in Kedah, Malaysia. The purpose of developing this local volume table was to get an accurate and precise estimate of tree volume in order to prepare forest management plan. There are few volume equations and volume tables that have been developed for the mangrove forest or a specific mangrove species, these equations and tables are applicable to a specific area or forest ecosystem $[1,2,3,4]$. To date, there has been no research conducted to construct volume equation or table for Sungai Merbok which is categorised as natural mangrove forest. Natural mangroves means most of the areas are regenerated naturally with very few intervention through planting activities.

\footnotetext{
${ }^{*}$ Corresponding author: Ismail $\mathrm{P}$

Forest Research Institute Malaysia (FRIM), Kepong 52109 Selangor, Malaysia.
} 
In terms of mangroves distribution in Malaysia, Hamdan [5] reported there was 629,038 ha of mangroves in year of 2017 as shown in Figure 1. Meanwhile total area of mangroves throughout the country based on state is shown in Table 1.

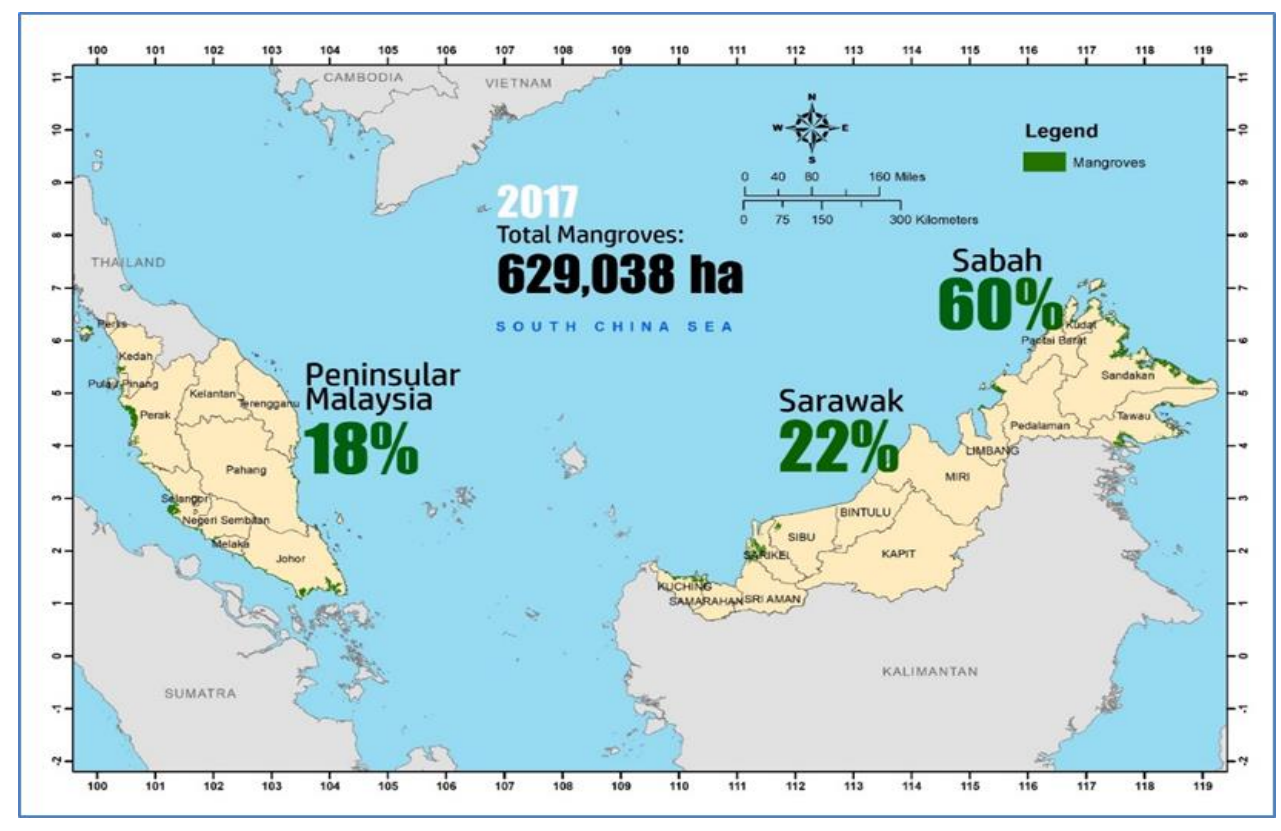

Figure 1 Distribution of mangroves in Malaysia over the year 2017

Table 1 Extents of mangroves in Malaysia in year 2017

\begin{tabular}{|l|l|}
\hline State & Mangroves (ha) \\
\hline Perlis & 49 \\
\hline Kedah & 7,725 \\
\hline Penang & 1,967 \\
\hline Perak & 44,990 \\
\hline Selangor & 20,853 \\
\hline Negeri Sembilan & 1,557 \\
\hline Melaka & 1,241 \\
\hline Johor & 26,818 \\
\hline Pahang & 3,759 \\
\hline Terengganu & 1,571 \\
\hline Kelantan & 422 \\
\hline Sub Total: Peninsular Malaysia & 110,953 \\
\hline Sabah & 378,195 \\
\hline Sarawak & 139,890 \\
\hline Total & 629,038 \\
\hline &
\end{tabular}




\section{Material and methods}

The study was undertaken in Sungai Merbok Forest Reserve in the District of Sungai Petani, Kedah (Figure 2). It is located at the western part of Kedah under the jurisdiction of Central Kedah Forest District. It is the biggest mangrove forest in Kedah, which covers an area of 3,076 ha. This represents a b o u t $50 \%$ of the total mangrove forest in the state. The total gazetted mangrove forest reserve in the state of Kedah is 6,201 ha [6]. Sungai Merbok mangrove forest was gazetted as forest reserve in 29.03.1951 and the only sizeable mangrove on the main land. The rest of the sizable mangroves in Kedah are situated in Langkawi.

Generally, mangroves stands in Merbok Forest Reserve is naturally regenerated. Only few compartments were utilized sustainably for timber/charcoal production [6]. Larger areas are being used for socioeconomics and ecotourism activities. In fact, Merbok River which is part of the reserve is main water channel for transportation among the local people (Figure 3).

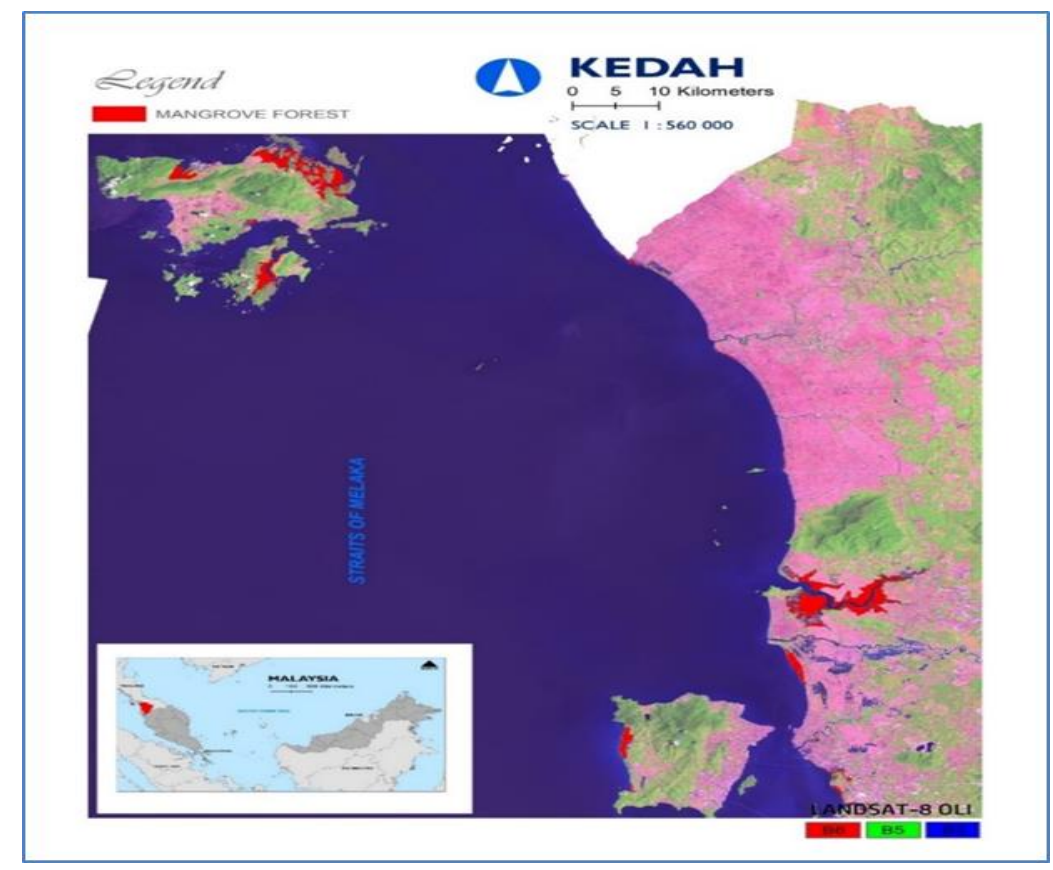

Figure 2 Distribution of mangroves in Kedah (Merbok \& Langkawi)

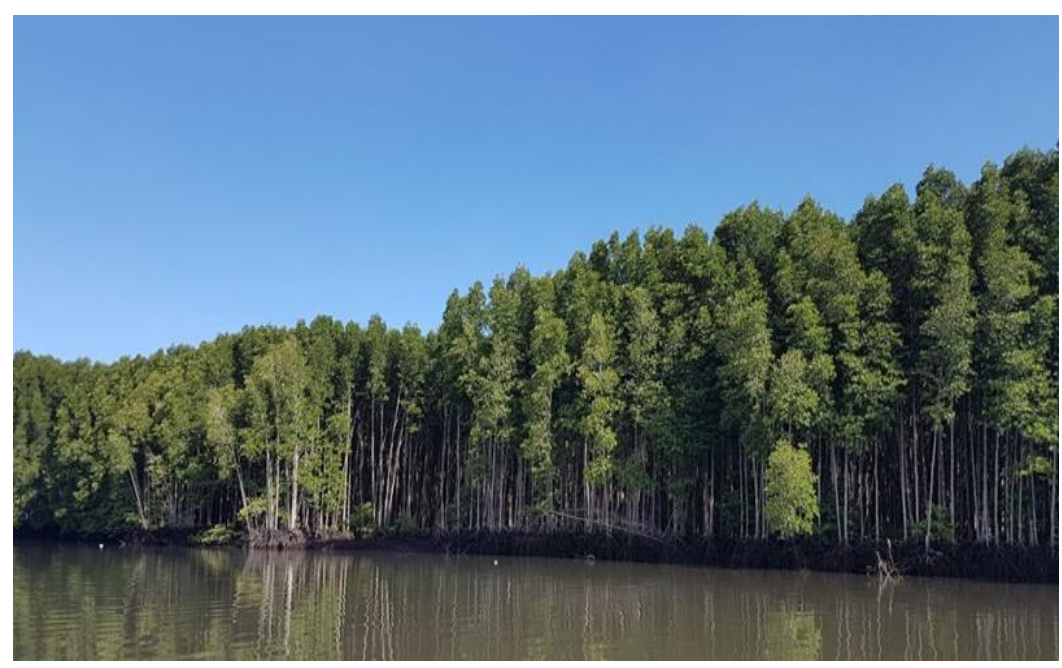

Figure 3 General condition of mangroves stand in Merbok Forest Reserve, Kedah

In preparing this volume table, only trees with $10 \mathrm{~cm}$ in diameter at breast height (dbh) and above were considered. The number of trees selected was based on diameter classes and species groups. The diameter were divided into five 
classes, while species group are categorised into Bakau and Non-Bakau. The Bakau group is referred to Rhizophora apiculata (Bakau minyak) and R. mucronata (Bakau kurap), while the Non-Bakau is referred to other than the both species such as Berus, Tengar, Tumu, Lenggadai, Perepat, Api-api, etc. Number of trees suggested as sample tree in each diameter class and species group is shown in Table 2.

Table 2 Number of trees suggested as sample tree

\begin{tabular}{|l|l|l|l|}
\hline \multirow{2}{*}{$\begin{array}{l}\text { Diameter Class } \\
\text { (cm) }\end{array}$} & \multicolumn{3}{|l|}{ Species Group } \\
\cline { 2 - 4 } & Bakau & $\begin{array}{l}\text { Non-Bakau } \\
\text { (Rhizophora spp.) }\end{array}$ & $\begin{array}{l}\text { Non-Bakau } \\
\text { (Non Rhizophora spp.) }\end{array}$ \\
\hline $10-<15$ & 30 & 20 & 30 \\
\hline $15-<20$ & 50 & 30 & 40 \\
\hline $20-<25$ & 50 & 30 & 40 \\
\hline $25-<30$ & 40 & 20 & 30 \\
\hline$>30$ & 30 & 20 & 20 \\
\hline Total & 200 & 120 & 160 \\
\hline
\end{tabular}

The selection of sample tree was based on following criteria:

- Individual tree for the sample must be straight in bole,

- The tree with defect such as forking or cankered on the bole was rejected,

- Merchantable length was measured up to the crown point (i.e. the first live branch that form the tree crown)

The measurements of parameters were done on felled trees. Parameters measured were: $\mathrm{dbh}$ in $\mathrm{cm}$, total height in meter, merchantable stem length in meter, stem diameter in $\mathrm{cm}$ (measured for every two meter interval till the crown point) and bark thickness in $\mathrm{cm}$. The dbh was measured before a tree was felled and taken at $1.3 \mathrm{~m}$ above the ground level i.e. for the tree without buttress/stilt roots or with buttress/stilt roots less than $1.0 \mathrm{~m}$. In the case of trees with buttress/stilt roots of more than $1.0 \mathrm{~m}$, the measurement was taken at $0.3 \mathrm{~m}$ above the buttress/stilt roots. The measurements of stem diameter over bark were taken at the bottom part of the stem (D1) and upper diameter (D2, D3, D4, ...Dn.) were recorded along the stem at every two meter intervals. The top diameter of the stem is taken at the crown point, which is at the first live branch that forms the tree crown.

For the bark thickness, the measurements were made by slashing out the bark using "parang" at the place where the measurement had to be taken. The bark thickness than was measured directly at notch by meter tape in $\mathrm{cm}$ at the nearest one decimal place. The bark thickness was measured at the D0, Dl and at every two meters interval along the stem i.e. at D2, D3, D4 and so on.

Data collected were analysed in two stages. The first stage involved computing the volume for each section and then summing up for the whole tree. The second stage involved regression analysis i.e. to fit the data to the selected equations in order to seek the best volume equation. Two formulas were used in order to compute tree volumes; Smalian and Newton formulas. The Smalian formula was used to measure the section of felled tree. However, in a condition where three diameter measurements were available the Newton formula was used. Newton formula has been recognised as the most accurate formula in calculating timber/tree volume while Smalian formula will give good accuracy if the stem is divided into short sections [8].

$\begin{array}{lll}\text { Smalian Formula } & : & V=h / 2\left(A_{b}+A_{u}\right) \\ \text { Newton Formula } & : & V=h / 6\left(A_{b}+4 A_{m}+A_{u}\right)\end{array}$

Where;

$\mathrm{V}=$ volume $\mathrm{h}=$ height (length), $\mathrm{Am}=$ cross sectional area at the middle of the tree, 
$A_{b}=$ cross sectional area at base and $A_{u}=$ cross sectional area at top.

Construction of local volume equation in this study was based on relation between dbh and volume (volume over bark and under bark). Scatter diagram technique was used to examine the relationship between the dbh and volume. This technique is the simplest and most commonly used procedure to examining the relationship between two variables [9]. Common regression model known as "power law" or "allometric" was used to construct the local volume table in this study. This is one of the commonly used equations to construct local volume table. The volume equation (power law or allometric) is given as:

$\mathrm{V}=\mathrm{B}_{\mathrm{o}} \mathrm{D}^{\mathrm{b} 1}+\varepsilon_{i}$

Where:

$\mathrm{V}=$ volume (over bark and under bark), $\mathrm{D}=$ diameter breast height $(\mathrm{dbh}), \mathrm{B}_{\mathrm{o}}=10^{\mathrm{b} 0}$ or $\mathrm{e}^{\mathrm{bo}}$,

$\mathrm{b}_{\mathrm{o}}$ and $\mathrm{b}_{1}=$ parameters to be estimated, $\varepsilon=$ random error with $\varepsilon_{i} \sim \mathrm{N}\left(0,6^{2}\right)$ and $i=$ index of observation i.e. individual tree.

The estimation procedure for estimating the parameters is through Gause-Newton procedure. However this model can also be estimated using the ordinary least square (OLS) technique through the transformation into natural log (ln) value:

$\ln \mathrm{V}=\ln \mathrm{b}_{0}+\mathrm{b}_{1} \ln \mathrm{D}$

According to [10], the purpose of transformation is to make the homogenous variance assumption more palatable and in the case of failure to have homogeneity of variance, transformation is designed to stabilise the error variance. Standard statistical measures requires the determination of mean error (ME), mean absolute error (MAE), sum of squared errors (SSE), mean squared error (MSE) and standard deviation of errors (SDE). Under this measure, the smallest MSE (or SSE) was normally used as an indicator to choose the best fit of the model. However, the used of MSE as a measure of accuracy has few limitations and can also create problems [11]. Thus alternative measures have been proposed, which those are dealing with percentage errors. These percentage errors are known as relatives measures, which required to determine the percentage error (PE), mean percentage error (MPE) and mean absolute percentage error (MAPE). In this study, the MSE and MAPE were used as indicators to choose the best fit of the model.

\section{Results and discussion}

Altogether there were 318 sample trees were measured from the study area. Of the total, 128 samples are Bakau species and another 190 samples are Non-Bakau species. The dbh for the Bakau species range from $10.1 \mathrm{~cm}$ to $39 \mathrm{~cm}$, while for the Non-Bakau the dbh range from $10 \mathrm{~cm}$ to $60.8 \mathrm{~cm}$. Tables 3 and 4 show the descriptive statistic calculated from the samples.

Table 3 Summary of parameters measured for Bakau Species

\begin{tabular}{|l|l|l|l|l|}
\hline Parameter & Mean & Standard Deviation & Min & Max \\
\hline Dbh $(\mathrm{cm})$ & 22.1 & 6.8 & 10.1 & 39.0 \\
\hline $\begin{array}{l}\text { Merchantable volume } \\
\text { over bark }\left(\mathrm{cm}^{3}\right)\end{array}$ & 0.2673 & 0.1696 & 0.0415 & 0.8153 \\
\hline $\begin{array}{l}\text { Merchantable volume } \\
\text { under bark }\left(\mathrm{cm}^{3}\right)\end{array}$ & 0.2514 & 0.1609 & 0.0397 & 0.7946 \\
\hline
\end{tabular}


Table 4 Summary of parameters measured for Non-Bakau species

\begin{tabular}{lllll}
\hline Parameter & Mean & Standard Deviation & Min & Max \\
\hline Dbh (cm) & 23.1 & 10.0 & 10.0 & 60.8 \\
$\begin{array}{l}\text { Merchantable volume } \\
\text { over bark (cm3) }\end{array}$ & 0.2234 & 0.2202 & 0.0194 & 1.4129 \\
$\begin{array}{l}\text { Merchantable volume } \\
\text { under bark (cm3) }\end{array}$ & 0.2136 & 0.2104 & 0.0162 & 1.3166 \\
\hline
\end{tabular}

Analysis of scatter diagram shows that there is a non-liner relation between dbh and gross stem volume, both for Bakau and Non-Bakau species (Figure 4). This indicates that the selected regression model (allometric) can be used to construct the local volume table since the model is a non-linear regression model. Thus, weighted least square (WLS) technique was used for estimation which provides efficient and consistent parameters.

Further analysis was carried out using the WLS on selected non-linear model besides transformation into the natural log value, which has been done in the earliest part of analysis. Transformation also one of the appropriate procedure that is designed to stabilise the error variance, which can easily analyse through OLS technique The heterogeneity of variance in this study probably due to the variation of tree sizes.
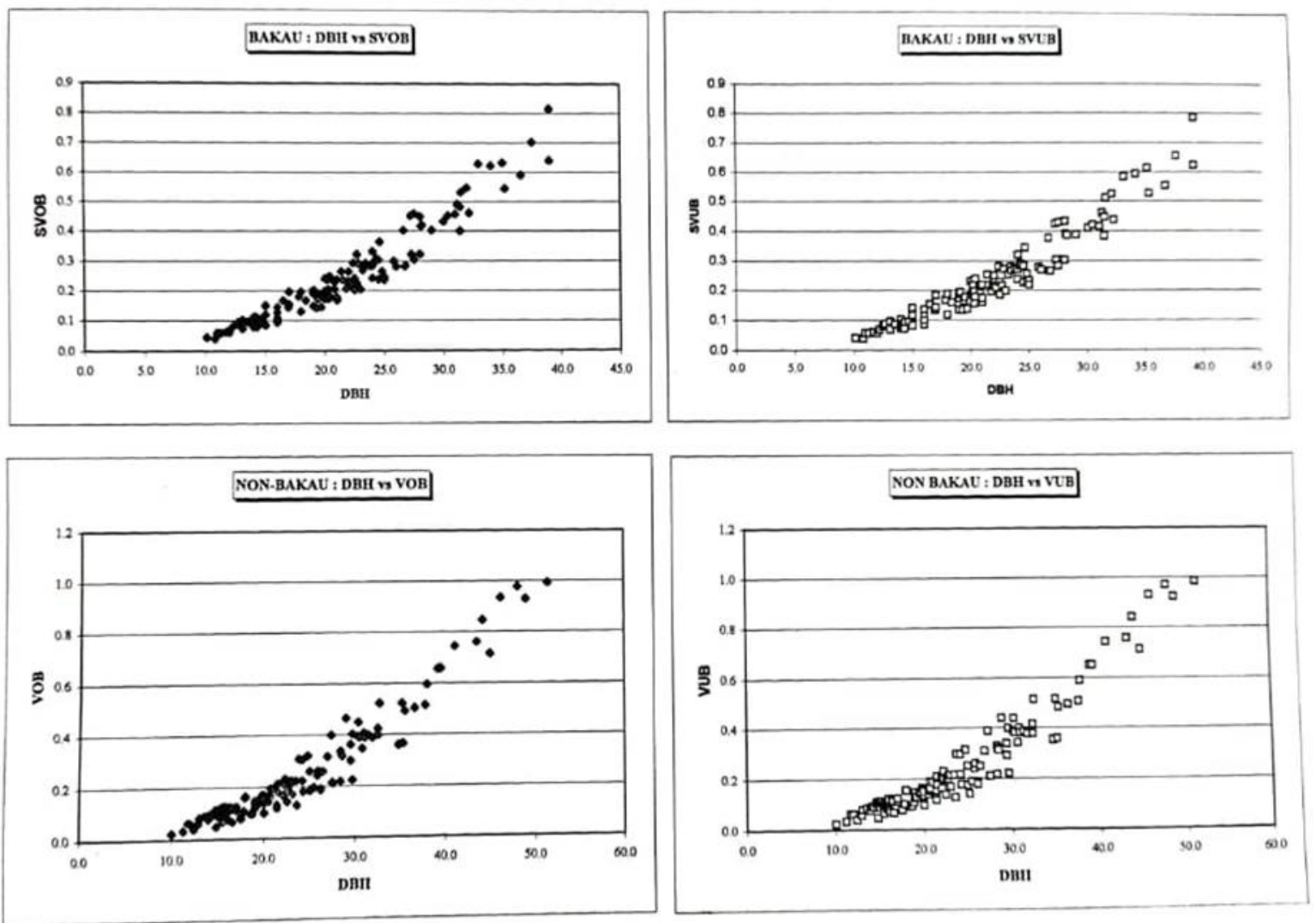

Figure 4 Scatter diagram for Bakau and Non-Bakau species

Tables 5 and 6 show the results of accuracy test i.e. for Bakau and Non-Bakau species respectively. The results show that the selected model (allometric model) by mean of WLS is the best fitted model to be used in constructing the local volume table for the study area. This is shown by lowest value of MSE and MAPE obtained from the analysis. In the case of Bakau species, the MSE and MAPE value for gross merchantable volume over bark $\left(\mathrm{V}_{\mathrm{Ob}}\right)$ are $0.0017 \%$ and $0.1271 \%$ respectively, while for gross merchantable volume under bark $\left(\mathrm{V}_{\mathrm{ub}}\right)$ are $0.0015 \%$ and $0.1260 \%$. 
Table 5 Test of accuracy on Bakau species

\begin{tabular}{|c|c|c|c|c|c|c|c|c|c|c|c|c|c|c|}
\hline \multirow[t]{2}{*}{ Model } & \multicolumn{7}{|c|}{ Gross volume over bark (VOB) } & \multicolumn{7}{|c|}{ Gross volume under bark (VUB) } \\
\hline & ME & MAE & SSE & MSE & SDE & MPE & MAPE & ME & MAE & SSE & MSE & SDE & MPE & MAPE \\
\hline $\begin{array}{l}\text { 1. } b_{0} * D^{b 1} \\
(\text { NLR) }\end{array}$ & 0.0073 & 0.0325 & 0.2365 & 0.0019 & 0.0433 & 0.0091 & 0.1277 & 0.0071 & 0.0304 & 0.2073 & 0.0016 & 0.0406 & 0.0099 & 0.1266 \\
\hline $\begin{array}{l}\text { 2. } b_{0} * D^{b 1} \\
\text { (WLS) }\end{array}$ & 0.0064 & 0.0315 & 0.2112 & 0.0017 & 0.0411 & 0.0065 & 0.1271 & 0.0057 & 0.0295 & 0.1873 & 0.0015 & 0.0387 & 0.0050 & 0.1260 \\
\hline $\begin{array}{l}\text { 3. } \ln \mathrm{V}=\mathrm{b}_{0}+\mathrm{b}_{1} * \ln \mathrm{D} \\
\text { (Trasformation) }\end{array}$ & 0.0014 & 0.0314 & 0.2197 & 0.0017 & 0.0418 & -0.0148 & 0.1281 & 0.0042 & 0.0302 & 0.2003 & 0.0016 & 0.0401 & -0.0043 & 0.1269 \\
\hline $\begin{aligned} V= & b_{0}+b_{1}^{*} D^{2} \\
& (\text { OLS })\end{aligned}$ & -0.0031 & 0.0319 & 0.2306 & 0.0018 & 0.0428 & -0.0307 & 0.1306 & -0.0011 & 0.0292 & 0.1843 & 0.0015 & 0.0383 & -0.0191 & 0.1267 \\
\hline $\begin{array}{l}V=b_{1} * D+b_{2} * D^{2} \\
\quad(O L S)\end{array}$ & .0 .0011 & 0.0319 & 0.2285 & 0.0018 & 0.0426 & -0.0149 & 0.1287 & 0.0007 & 0.0293 & 0.1838 & 0.0015 & 0.0382 & -0.0129 & 0.1263 \\
\hline $\begin{array}{l}V=b_{0}+b_{1} * D+b_{2} * D^{2} \\
(O L S)\end{array}$ & -0.0009 & 0.0319 & 0.2287 & 0.0018 & 0.0426 & -0.0245 & 0.1301 & -0.0007 & 0.0301 & 0.1996 & 0.0016 & 0.0398 & -0.0243 & 0.1293 \\
\hline & $\begin{array}{r}\text { Not } \\
\text { ME : } \\
\text { MAE : } \\
\text { SSE : } \\
\text { MSE : } \\
\text { SDE : } \\
\text { MPE : } \\
\text { MAPE : }\end{array}$ & $\begin{array}{l}\text { te : } \\
\text { Mean ern } \\
\text { Mean ab } \\
\text { Sum of s } \\
\text { Mean sq } \\
\text { Standard } \\
\text { Mean pe } \\
\text { Mean ab }\end{array}$ & $\begin{array}{l}\text { ror } \\
\text { solute err } \\
\text { squared er } \\
\text { uared errc } \\
\text { deviatior } \\
\text { rcentage } \\
\text { solute per }\end{array}$ & $\begin{array}{l}\text { ror } \\
\text { rrors } \\
\text { or } \\
\text { n of error } \\
\text { error } \\
\text { rcentage }\end{array}$ & error & & & & & & & & & \\
\hline
\end{tabular}

In the case of Non-Bakau species, the Vob clearly shows the lowest value, both in MSE and MAPE for selected equation, which are $0.008 \%$ and $0.4370 \%$ respectively. However, for the $V_{u b}$ only the MSE value for the selected equation shows the lowest value. Meanwhile, MAPE for Model 3 (Transformation) shows lowest value but the different with the another two equations are not significant i.e only 0.0001 (compared with Models 1 a n d 2). Therefore, the weighted allometric equation is the suitable and best fitting model for both Bakau and Non-Bakau species due to the smallest value of MSE and MAPE.

Table 6 Test of accuracy on Non-Bakau species.

\begin{tabular}{|c|c|c|c|c|c|c|c|c|c|c|c|c|c|c|}
\hline \multirow[t]{2}{*}{ Model } & \multicolumn{7}{|c|}{ Gross volume over bark (VOB) } & \multicolumn{7}{|c|}{ Gross volume under bark (VUB) } \\
\hline & ME & MAE & SSE & MSE & SDE & MPE & MAPE & ME & MAE & SSE & MSE & SDE & MPE & MAPE \\
\hline $\begin{array}{l}\text { 1. } b_{0} \cdot D^{b l} \\
(N L R)\end{array}$ & 0.0015 & 0.0618 & 1.5673 & 0.0087 & 0.0936 & -0.1489 & 0.4376 & 0.0013 & 0.0589 & 1.4369 & 0.0080 & 0.0896 & -0.1506 & 0.4391 \\
\hline $\begin{array}{l}\text { 2. } b_{0} \cdot D^{b l} \\
(\text { WLS) }\end{array}$ & 0.0026 & 0.0602 & 1.4387 & 0.0080 & 0.0897 & -0.1671 & 0.4370 & 0.0025 & 0.0574 & 1.3119 & 0.0073 & 0.0856 & -0.1695 & 0.4391 \\
\hline $\begin{array}{l}\text { 3. In } \mathrm{V}=\mathrm{b}_{0}+\mathrm{b}_{1} \cdot \ln \mathrm{D} \\
\text { (Trasformation) }\end{array}$ & 0.0004 & 0.0618 & 1.5786 & 0.0088 & 0.0936 & -0.1556 & 0.4385 & 0.0016 & 0.0589 & 1.4341 & 0.0080 & 0.0896 & -0.1500 & 0.4390 \\
\hline $\begin{aligned} V= & b_{0}+b_{1} \cdot D^{2} \\
& (O L S)\end{aligned}$ & -0.0192 & 0.0611 & 1.7950 & 0.0100 & 0.1001 & .0 .3493 & 0.5016 & -0.0139 & 0.0574 & 1.5497 & 0.0086 & 0.0931 & -0.3267 & 0.4942 \\
\hline $\begin{aligned} V & =b_{1} \cdot D+b_{2} \cdot D^{2} \\
& (O L S)\end{aligned}$ & -0.0211 & 0.0595 & 1.6482 & 0.0092 & 0.0960 & -0.3562 & 0.4940 & -0.0203 & 0.0568 & 1.5017 & 0.0083 & 0.0916 & -0.3613 & 0.4982 \\
\hline $\begin{array}{l}V=b_{0}+b_{1} \cdot D+b_{2} \cdot D^{2} \\
(O L S)\end{array}$ & -0.0163 & 0.0620 & 1.5582 & 0.0087 & 0.0933 & -0.2091 & 0.4634 & -0.0154 & 0.0591 & 1.4136 & 0.0079 & 0.0889 & -0.2086 & 0.4649 \\
\hline & $\begin{array}{r}\text { Not } \\
\text { ME : } \\
\text { MAE : } \\
\text { SSE : } \\
\text { MSE : } \\
\text { SDE : } \\
\text { MPE : } \\
\text { MAPE : }\end{array}$ & $\begin{array}{l}\text { ote : } \\
\text { Mean err } \\
\text { : Sum of s } \\
\text { : Mean sq } \\
\text { Standard } \\
\text { Mean pe } \\
\text { Mean ab }\end{array}$ & $\begin{array}{l}\text { ror } \\
\text { solute erro } \\
\text { squared en } \\
\text { puared erro } \\
\text { deviation } \\
\text { ercentage e } \\
\text { solute per }\end{array}$ & $\begin{array}{l}\text { ror } \\
\text { trrors } \\
\text { ror } \\
\text { on of error } \\
\text { error } \\
\text { ercentage }\end{array}$ & $\begin{array}{l}\text { rs } \\
\text { error }\end{array}$ & & & & & & & & & \\
\hline
\end{tabular}

Based on the accuracy test, allometric model estimated by the WLS was selected as the best model for constructing the volume equation. This model was used to develop the local volume equation for Sungai Merbok Forest Reserve. 
The final volume equations to construct the local volume table for Merbok Forest Reserve are as follows (Table 7):

a) Bakau Species

i) Gross Volume Over Bark ( $\left.\mathrm{V}_{\mathrm{ob}}\right)$

$\mathrm{V}_{\mathrm{ob}}=0.00045 \mathrm{D}^{2.02248}$

ii) Gross Volume Under Bark ( $\left.\mathrm{V}_{\mathrm{ub}}\right)$

$\mathrm{V}_{\mathrm{ub}}=0.00040 \mathrm{D}^{2.04390}$

b) Non-Bakau species

i) Gross Volume Over Bark ( $\left.V_{o b}\right)$

$\mathrm{V}_{\mathrm{ob}}=0.00088 \mathrm{D}^{1.69929}$

ii) Gross Volume Under Bark ( $\left.V_{u b}\right)$

$\mathrm{V}_{\mathrm{ub}}=0.00084 \mathrm{D}^{1.70310}$

Table 7 Local volume table for Sungai Merbok Forest Reserve

\begin{tabular}{|c|c|c|c|c|}
\hline \multirow[t]{3}{*}{ Dbh (cm) } & \multicolumn{4}{|c|}{ Gross stem volume $\left(\mathrm{m}^{3}\right)$} \\
\hline & \multicolumn{2}{|c|}{ Bakau Species } & \multicolumn{2}{|c|}{ Non-Bakau Species } \\
\hline & *Over bark & Under bark & ${ }^{*}$ Over bark & Under bark \\
\hline 10.0 & 0.0474 & 0.0443 & 0.0440 & 0.0424 \\
\hline 10.1 & 0.0484 & 0.0452 & 0.0448 & 0.0431 \\
\hline 10.2 & 0.0493 & 0.0461 & 0.0455 & 0.0439 \\
\hline 10.3 & 0.0503 & 0.0470 & 0.0463 & 0.0446 \\
\hline 10.4 & 0.0513 & 0.0479 & 0.0471 & 0.0453 \\
\hline 10.5 & 0.0523 & 0.0489 & 0.0478 & 0.0461 \\
\hline 11.0 & 0.0575 & 0.0538 & 0.0518 & 0.0499 \\
\hline 12.0 & 0.0685 & 0.0642 & 0.0600 & 0.0578 \\
\hline 13.0 & 0.0806 & 0.0757 & 0.0688 & 0.0663 \\
\hline 14.0 & 0.0936 & 0.0880 & 0.0780 & 0.0752 \\
\hline 15.0 & 0.1076 & 0.1014 & 0.0877 & 0.0846 \\
\hline 16.0 & 0.1226 & 0.1157 & 0.0979 & 0.0944 \\
\hline 17.0 & 0.1386 & 0.1309 & 0.1085 & 0.1047 \\
\hline 18.0 & 0.1556 & 0.1471 & 0.1196 & 0.1154 \\
\hline 19.0 & 0.1736 & 0.1643 & 0.1311 & 0.1265 \\
\hline 20.0 & 0.1925 & 0.1825 & 0.1430 & 0.1381 \\
\hline 21.0 & 0.2125 & 0.2016 & 0.1554 & 0.1500 \\
\hline
\end{tabular}


World Journal of Advanced Research and Reviews, 2020, 07(02), 264-273

\begin{tabular}{|l|l|l|l|l|}
\hline 22.0 & 0.2335 & 0.2217 & 0.1681 & 0.1624 \\
\hline 23.0 & 0.2554 & 0.2428 & 0.1813 & 0.1752 \\
\hline 24.0 & 0.2784 & 0.2649 & 0.1949 & 0.1883 \\
\hline 25.0 & 0.3024 & 0.2879 & 0.2089 & 0.2019 \\
\hline 26.0 & 0.3273 & 0.3120 & 0.2233 & 0.2158 \\
\hline 27.0 & 0.3533 & 0.3370 & 0.2381 & 0.2302 \\
\hline 28.0 & 0.3802 & 0.3630 & 0.2533 & 0.2449 \\
\hline 29.0 & 0.4082 & 0.3900 & 0.2689 & 0.2599 \\
\hline 30.0 & 0.4372 & 0.4180 & 0.2848 & 0.2754 \\
\hline 35.0 & 0.5971 & 0.5728 & 0.3701 & 0.3581 \\
\hline 40.0 & 0.7823 & 0.7525 & 0.4644 & 0.4495 \\
\hline
\end{tabular}

\section{Conclusion}

Conclusion and recommendations from the study are as follows:

- The local volume table has been recognised as one of the tools that can be used for providing the estimates of volume in a given mangrove area.

- There was a non-linear relationship between diameter at breast height and gross stem volume for Bakau and Non-Bakau species.

- Local volume table for Sungai Merbok Forest R e s e rve were constructed based on "allometric model" which were solved by mean of weighted least square (WLS).

- Every mangrove forest should have its own local volume equation. Practically, the local volume table constructed in this study is applicable only to Sungai Merbok Mangrove Forest Reserve, however, for those mangrove areas that yet to have their own volume equations may use this equations provided relative similarity in terms of stands condition and management practices.

\section{Compliance with ethical standards}

\section{Acknowledgments}

Acknowledgements to staff of Forestry Department of Kedah, Malaysia for assisting in field study and data collection. The authors also would like to acknowledge Ashari Muktar and Awang Noor Abd. Ghani of Universiti Putra Malaysia for their advice and inputs in conducting this study.

\section{Disclosure of conflict of interest}

None

\section{References}

[1] Vincent AJ and Sandrasegaran K. (1965). A collection of miscellanous volume tables constructed for use in the Malayan forest service through to the 30th June, 1965. Malay. For. Research Pamphlet 46. 70.

[2] AIFM. (1989). Preliminary inventory report, Matang Mangrove Forest, Perak. Asean Institute of Forest Management (AIFM), Kuala Lumpur (unpublished).

[3] Ismail P, Ashari M, Mohd Nasir H and Azian M. (2007). Species composition and stocking of Sungai Kerang Mangroves in Matang, Perak. Malaysian Forester, 70(1), 67-80. 
[4] Ismail P, Abd Rahman K, Wan Mohd Shukri WA, Samsudin M and Harfendy O. (2011). Development of a local volume table (LVT) for Gonystylus bancanus in Pekan Forest Reserve (Chapter 8). In Ismail, P. \& Ismail, H (eds.), Technical information on optimum harvesting regimes of peat swamp forest in Peninsular Malaysia. Published by FRIM under the ITTO-CITES Project, 73-79.

[5] Hamdan O. (2019). Assessment of Mangrove Changes in Malaysia Using Remote Sensing. National Seminar on Mangroves and Coastal Areas, 10-11 September 2019, Hotel Park Avenue, Sungai Petani, Kedah.

[6] FD Kedah. (2019). Mangroves Management Plan for Kedah 2020-2029. Forestry Department of Kedah (unpublished), 390.

[7] Hamdan O, Khali Aziz H, Shamsudin I and Raja Barizan RS. (2012). Status of mangroves in Peninsular Malaysia. Forest Research Institute Malaysia, 134.

[8] Husch B, Miller CI and Beers TW. (1982). Forest mensuration. John Wiley \& Sons, New York. 402.

[9] Gomez KA and Gomez A. (1984). Statistical procedures for agricultural research. 2nd Edition. John Wiley \& Sons, Canada, 680.

[10] Myers RH. (1986). Classical and modern regression with applications. Duxbury Press, Boston, Massachusetts. 359.

[11] Makridakis S, Wheelwright SC and McGee VE. (1983). Forecasting: methods and applications. 2nd ed. John Wiley and Sons, New York, 926. 